Tyndale Bulletin 70.2 (2019) 245-267

\title{
THE ROLE OF SEMITIC CATCHWORDS IN INTERPRETING THE EPISTLE OF JAMES
}

\author{
Daniel K. Eng \\ (DanielKEng@gmail.com)
}

\begin{abstract}
Summary
This article examines the arrangement of the Epistle of James in light of Semitic documents that display catchword association. James shows evidence of being a compilation, with adjacent sections frequently connected by a common cognate. After identifying patterns of catchword association in the Hebrew Bible, LXX, and Qumran, the article identifies instances of catchword association in the Epistle of James. Finally, some conclusions are drawn for James, including recommendations about the study of its genre, provenance, structure, and interpretation. ${ }^{1}$
\end{abstract}

\section{Introduction}

This article examines the interpretation of the Epistle of James in light of Semitic documents that display catchword association. James shows evidence of having adjacent sections frequently connected by a common cognate, called a catchword, or Stichwort. While not necessarily displaying logical progression, the epistle shows consistency with an intentional Semitic custom of connecting material by catchword. After identifying patterns of catchword association in Jewish documents, we will examine similar arrangements in James and

1 Earlier versions of this article were presented at the Oxford-Cambridge Biblical Studies Conference, the British New Testament Conference, and the Society of Biblical Literature Annual Meeting, all in 2018. The author would like to thank those who gave helpful advice and feedback, especially K. Lawson Younger Jr., C. Hassell Bullock, J. LaRae Ferguson, David A. deSilva, Darian Lockett, Andrew Yee, and Jonathan Robinson. 
offer recommendations on how the identification of catchword association impacts the interpretation of the epistle.

For the purposes of this study, the phrase 'catchword association' refers to the adjacent placing of distinct sections of text, linked by a common lexeme. ${ }^{2}$ In his 1983 article, ${ }^{3}$ H. Van Dyke Parunak offers a delineation of various methods of structuring a biblical document that largely trace back to continental scholar David Müller. ${ }^{4}$ Müller pointed to a structuring technique called concatenation, which refers to the 'recurrence of similar features at the end of one structural unit and the beginning of the next'. ${ }^{5}$ Parunak goes on to define different categories of linguistic similarities that can occur between two units linked by concatenation. ${ }^{6}$ For the present study we will focus on common lexemes that occur in consecutive sections, with the most compelling cases being what Parunak calls lexical similarity, a common lexeme occurring at the adjoining ends of both sections.

Concatenation based on lexical similarity can be diagrammed in this way, with the boxes representing units of text and the dots representing a particular repeated lexeme:

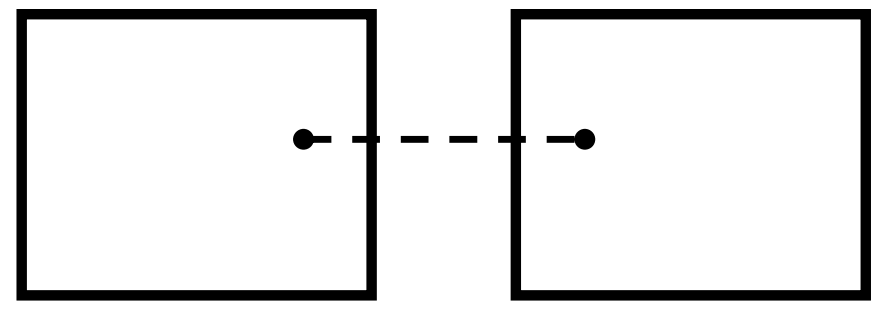

2 This is distinct from the phenomenon which Shamir Yona and Ariel Ram Pasternak call anadiplosis, a word or group of words appearing at the end of a given stich, verset, or verse repeated at the beginning of the following stich, verset, or verse. The authors also call this device concatenation. They demonstrate that anadiplosis occurs within the same section of section or even the same verse, such as עֶ? עִ at the end of Ps. 121:1 and beginning of Ps. 121:2, or the repetition of בצלם in consecutive clauses in Gen. 1:27. See Shamir Yona and Ariel Ram Pasternak, "Concatenation in Ancient Near East Literature, Hebrew Scripture and Rabbinic Literature", Review of Rabbinic Judaism 22 (2019): 46-92.

3 H. Van Dyke Parunak, 'Transitional Techniques in the Bible', JBL 102 (1983): 525. Parunak reports on this school of thought to supplement the American and British lineage that looked for patterns like alternation and chiasm.

4 David Heinrich Müller, Die Propheten in ihrer ursprünglichen Form, die Grundgesetze der ursemitischen Poesie, erschlossen und nachgewiesen in Bibel, Keilinschriften und Koran und in ihren Wirkungen erkannt in den Chören der grieschen Tragödie (Wien: A. Hölder, 1896).

5 Parunak, 'Transitional Techniques in the Bible', 526.

6 These are phonological, morphological, lexical, syntactic, and logical. Parunak, 'Transitional Techniques in the Bible', 528. 
This study brings the Epistle of James into comparison with Semitic documents that display catchword association for three reasons. First, the epistle is addressed to the twelve tribes in the Diaspora, as stated in James $1: 1$. There is nothing in the text that refutes the view that the audience of the epistle is ethnically Jewish ${ }^{7}$ and familiar with catchwords as a literary device. Second, while James contains easily delineable sections, the document as a whole has proven to be a challenge to outline. A glance at commentaries offers many different outlines to James, seemingly as many as there are commentators. As we will see below, Semitic documents often contain easily decipherable sections that do not necessarily progress in logic from one section of text to the next. Third, catchword association in James has been observed by a number of scholars, as there are lexemes that are repeated across adjacent sections of James, which we will examine below. This study aims to make two contributions to biblical studies: (1) a delineation of the usage of catchwords in Semitic documents across different genres; and (2) examining the content of James in light of these documents.

\section{Examining Semitic Documents}

In each example from Semitic documents below, we will examine how a common lexeme occurs in two adjacent sections of text, linking the two sections together. Scholars have identified a myriad of catchword associations. While some are more compelling than others, this article will present prominent instances across different genres.
Principle
Brief description
1
Disparity of the sections
2
Scarcity of the catchword in the entire document
3
More than one catchword connecting the two sections
4
Catchwords occurring at the end of one section and the beginning of the next
5 Catchwords in both Hebrew and Greek
$6 \quad$ Catchword is not related to the main topic
7 Catchword is used in different ways in the two sections

7 Luke Timothy Johnson, Brother of Jesus, Friend of God: Studies in the Letter of James (Grand Rapids: Eerdmans, 2004): 37; Craig L. Blomberg and Mariam J. Kamell, James (ZECNT; Grand Rapids: Zondervan, 2008): 28. 
This study will employ seven principles in identifying instances of catchword association, delineated in the table above. First, the more disparate the sections are, the more likely it is the case that they are adjacent based on a common lexeme or cognate. Second, the rarer the catchword(s) is in the entire document, the more likely it is being used to connect sections of text within the document. Third, catchword association is more likely to be the case if there is more than one word connecting the two sections. Fourth, catchword association can take different forms. Most notably, the catchword or catchwords in view often occur close to the end of the previous section, closer to the beginning of the next section, or both. The technique of catchwords specifically occurring at the adjoining ends of consecutive sections is the specific arrangement Müller categorises as concatenatio and Parunak calls 'the link'. ${ }^{8}$ Fifth, catchword association is even more remarkable if it occurs in both Hebrew and Greek, for this suggests the plausibility that the translators were aware of such connections and kept them in their translation. Instances of this arrangement in both languages will be highlighted below. Sixth, catchword association is more convincing if the repeated word is not related to the main topic of discussion in one or both of the texts. Seventh, catchword association is also more compelling if the repeated word is used in different ways in the two texts. With these principles in mind, we will examine some instances of catchword association below.

\subsection{Leviticus}

Leviticus 17 shows evidence that it is linked to the previous material through catchwords. The disparity between the Holiness Code in Leviticus (starting in ch. 17) and the material directly preceding has contributed to suggestions that Leviticus is a compilation of preexisting material. ${ }^{9}$ Often said to be of a different source from the priestly material in Leviticus $1-16,{ }^{10}$ there is a transition from cultic

8 Parunak, 'Transitional Techniques in the Bible', 530-31.

9 There are other factors that lead scholars to suggest that Leviticus is an arrangement of pre-existing material. See Lloyd R. Bailey, Leviticus-Numbers (SHBC; Macon, Georgia: Smyth \& Helwys, 2005): 23-25. Sometimes the Holiness Code is demarcated as chapters 17-27. See Jacob Milgrom, Leviticus 17-22: A New Translation with Introduction and Commentary (AB, 3B; New York: Doubleday, 2000): viii; Gordon Wenham, Exploring the Old Testament: The Pentateuch (London: SPCK, 2003): 95.

10 Jacob Milgrom, Leviticus 1-16: A New Translation with Introduction and Commentary (AB, 3A; New York: Doubleday, 1991): 61. 
practice to ethical content at Leviticus $17 .{ }^{11}$ The Holiness Code, which is often punctuated by the calls to be holy as YHWH is holy, is linked to the previous chapter by the term פִִּ the act of atoning. This is found in Leviticus 17:11 and also occurs throughout chapter 16 $(16: 6,10,11,16,17,18,20,24,27,30,32,33,34)$. Jacob Milgrom views Leviticus 17 as a chiasm, centred at 17:10-12.12 The term for atoning, then, would connect this centre to the previous chapter. The disparate nature of Leviticus 16 and 17 (Principle 1) and the fact that the connection occurs in both Hebrew and Greek (Principle 5) together suggest that these passages are connected by catchword.

Even more compelling evidence that Leviticus 16 and 17 are connected by catchword is found with the term שָׁעִיר (goat), which is not the main topic of Leviticus 16 or 17 (Principle 6). Chapter 17 begins with commands regarding the slaughter and consumption of meat. ${ }^{13}$ Umberto Cassuto points out that these commands that begin the Holiness Code come right after the material about the Day of Atonement with the connection of goats. In the first command, animals for sacrifice are to be slaughtered in the correct place, and the people are not to sacrifice to the goat demons, or satyrs (Principle 7). The term שָׁעִ in the Holiness Code connects to the repeated instances of the goats of sacrifice for the Day of Atonement (16:5,7,8,9,10,15,18,20,21, 22,26,27). ${ }^{14}$ Parunak refers to this connection of a repeated keyword in one unit and the extreme of an adjoining unit as 'the linked keyword', ${ }^{15}$ a subset of the larger category of concatenation.

\subsection{Numbers}

Numbers 5 contains a series of passages that appear disparate (Principle 1). After commands to put out those who are unclean (5:14 ), instructions about restitution for sin are given (5:5-10), and then instructions about wives suspected of unfaithfulness (5:11-29). The section regarding the suspected wife is 'attracted' to the section about restitution for sin through a catch phrase. ${ }^{16}$ While the root מעל occurs

\footnotetext{
11 Bailey, Leviticus-Numbers, 197.

12 Milgrom, Leviticus 17-22, 1449.

13 Milgrom, Leviticus 17-22, 1449.

14 Umberto Cassuto, 'The Sequence and Arrangement of Biblical Sections' in Biblical and Oriental Studies, Volume 1: Bible (Jerusalem: Magnes; tr. from Hebrew and Italian, 1973): 2-3.

15 Parunak, 'Transitional Techniques in the Bible', 532.

16 Cassuto, 'The Sequence and Arrangement of Biblical Sections', 4.
} 
often in Numbers, its doubling in the form of a cognate accusative occurs only three times (Principle 2), in these very instances in Numbers 5:

Numbers 5:6 Speak to the Israelites: When a man or a woman wrongs another, breaking faith with the LORD, that person incurs guilt, (NRSV)

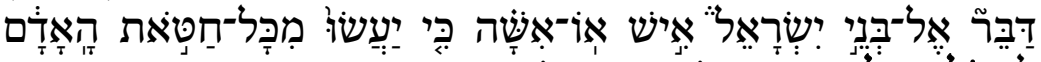

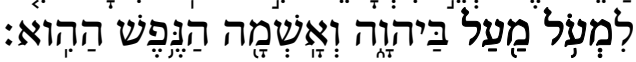

Numbers 5:12 Speak to the Israelites and say to them: If any man's wife goes astray and is unfaithful to him,

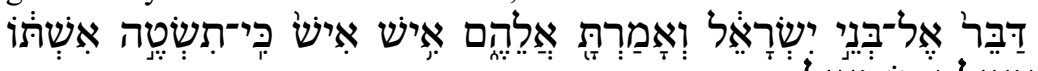

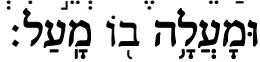

Numbers $5: 27 \mathrm{~b} \ldots$ if she has defiled herself and has been unfaithful to her husband ...

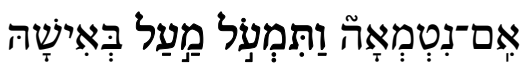

Notably, the Old Greek of Numbers 5:6 and 5:12 also displays the concatenation identified by Müller (Principle 5), as they are the only places in numbers that contain the corresponding term $\pi \alpha \rho \rho \rho \alpha \omega$ (Principle 2). ${ }^{17}$

\subsection{Psalms}

Franz Delitzsch advises that the 'principle of homogeneity' is a Semitic custom that often governs the grouping of the psalms. ${ }^{18}$ More recently, Erich Zenger championing Psalterexegese, the study of the psalms as a unity rather than as individual psalms (Psalmenexegese), demonstrates how Stichwortbeziehung connects consecutive psalms. ${ }^{19}$ Space allows for only several examples in the Psalter here. Zenger demonstrates the concatenation of the name of YHWH at the end of Psalm 7 and beginning of Psalm 8 (7:18 and 8:2) as well as the end of Psalm 8 and the beginning of Psalm 9 (8:10 and 9:3). Delitzsch likewise shows the

\footnotetext{
17 The subjunctive is doubled with the participle in 5:6 ( $\pi \alpha \rho 1 \delta \omega \nu \nu \pi \alpha \rho i \delta \eta \eta)$ but 5:12 uses the related term $\dot{\pi} \varepsilon \rho \rho \rho \alpha ́ \omega$ in the participle. Neither occurs in 5:27.

18 Franz Delitzsch, A Commentary on the Book of Psalms (New York: Funk \& Wagnalls; tr. from German, 1883): 26.

19 Erich Zenger, 'Psalmenexegese und Psalterexegese: Eine Forschungsskizze' in The Composition of the Book of Psalms, ed. Erich Zenger (BETL, 238; Leuven: Peeters, 2010): 31-34.
} 


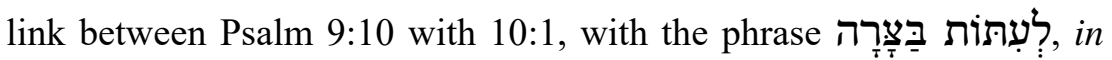
times of trouble. ${ }^{20}$ These pairings demonstrate Principles 1, 3, and 5. Amos Hakham highlights the placement of Psalm 25 based on the verb נשא (lift) in 25:1, which occurs six times in Psalm 24 (24:4,5,7,9) used in different ways (Principle 7). Hakham also sees the connections

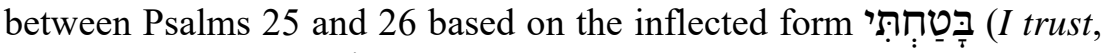
25:2 and 26:1) and (integrity, 25:21 and 26:1; Principles 3, 4). ${ }^{21}$ Delitzsch also points out that Psalms 34 and 35 are placed together, being the only Psalms in which the 'angel of the LORD' is mentioned (Ps. 34:8; 35:5-6; Principles 1, 2, 3). ${ }^{22}$ Notably, these are the only two

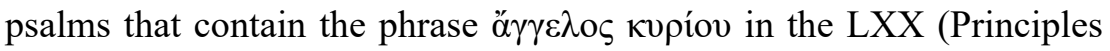
2, 4). He also links Psalms 55 and 56 based on a connection of the root יונה (55:7 and 56:1). ${ }^{23}$ This connection is particularly compelling because of (1) the rarity of this root in the Psalter (only occurring one other time, 68:14), and (2) the fact that it is used in different ways, describing a dove in 55:7 and a proper name in 56:1 (Principles 2, 7). Michael G. McKelvey links Psalm 90:10 and 91:5 through the root עוף (to fly), of which the verbal form only occurs four times in the Psalter (Principle 2). ${ }^{24}$ This connection of catchword association is also particularly compelling, as McKelvey correctly points out that they are used in different contexts: the 'brevity of life' in 90:10 and the protection from flying arrows in 91:5 (Principle 1, 6). He also connects Psalms 90 and 91 through the terms אֶלֶ (thousand, 90:4; 91:7) and מָעוֹן (dwelling place, 90:1; 91:9), both of which are rare in the Psalter and are used in different contexts in these consecutive psalms (Principles 2, 7). ${ }^{25}$ David M. Howard $\mathrm{Jr}$ notes the concatenation between the end of Psalm 96 and the beginning of Psalm 97, linked

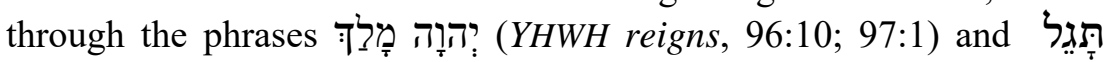
הָאָר (let the earth rejoice, 96:11; 97:1). He further points out that the two psalms are linked through other key words, especially the only

20 Delitzsch, Psalms, 27. Note that Pss. 9 and 10 are listed as one psalm in the LXX, with 10:1 in the MT being 9:22 in the LXX.

21 Amos Hakham, The Bible: Psalms with the Jerusalem Commentary (Jerusalem: Mosad Harav Kook, 2003), 1: xxxiv.

22 Delitzsch, Psalms, 26.

23 Delitzsch, Psalms, 26.

24 The other two instances are Ps. 18:11 and Ps. 55:7.

25 Michael G. McKelvey, Moses, David and the High Kingship of Yahweh: A Canonical Study of Book IV of the Psalter (Piscataway, New Jersey: Gorgias, 2014): 47-48. 
occurrences of אֶלהִ (worthless idols, 96:5; 97:7) in the Psalter (Principle 2). ${ }^{26}$ Michael K. Snearly notes the concatenation between Psalms 108-100 through the noun יָמִין (right hand, 108:7; 109:6,31; $110: 1,5)$. He makes an even stronger case for concatenation through the root ראש (head or beginning), which is used in different contexts (Principle 7) in consecutive Psalms (108:9; 109:25; 110:6,7; 111:10). ${ }^{27}$

\subsection{Proverbs}

While there is no consensus on subunits within the book of Proverbs, the arrangements show evidence of deliberate placement, especially with the usage of catchword association. ${ }^{28}$ Ted Hildebrandt, arguing against the view that Proverbs is 'thrown together willy-nilly', makes a case for pairs of proverbs linked together through different means, including catchwords. ${ }^{29} \mathrm{He}$ demonstrates how Proverbs 26:4-5 are connected by 'multi-catchword cohesion', with the repeated

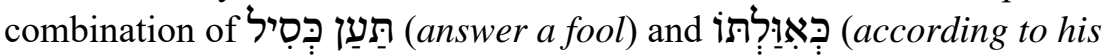
folly, Principle 3). ${ }^{30}$ The cohesion also occurs in the LXX (Principle 6)

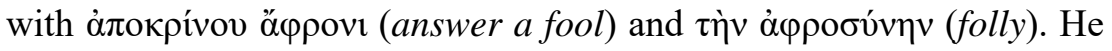
further points out the multi-catchword cohesion in Proverbs 15:8-9,

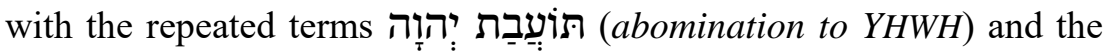
root רשע (wicked) in both sayings (Principle 3). ${ }^{31}$ The association also occurs in the LXX, with $\beta \delta \varepsilon \dot{\lambda} v \gamma \mu \alpha$ кvpí (abomination to the Lord) and $\dot{\alpha} \sigma \varepsilon \beta \eta \dot{s}$ (ungodly, Principle 6). There is also multi-catchword connection in Proverbs 26:20-21 with the words يִ עִצים (fire and trees; also $\pi \tilde{v} \rho$ and $\xi v ́ \lambda o v$ in the LXX, Principles 3, 5) used in different contexts. In addition to multi-catchword parallels, Hildebrandt goes on to list more lower-frequency catchwords (such as gold in 25:11-12 and fruit in 18:20-21) in consecutive proverbs to argue against coincidental placement (Principle 2). ${ }^{32}$

26 David M. Howard Jr, The Structure of Psalms 93-100 (BJSUCSD, 5; Winona Lake, Indiana: Eisenbrauns, 1997): 142-43.

27 Michael K. Snearly, The Return of the King: Messianic Expectation in Book V of the Psalter (LHBOTS, 624; London: Bloomsbury T\&T Clark, 2015): 118.

28 For a helpful summary of the issues involved in determining subunits in Proverbs, see Roland E. Murphy, Proverbs (WBC, 22; Nashville: Thomas Nelson, 2000): 64-69.

29 Theodore A. Hildebrandt, 'Proverbial Pairs: Compositional Units in Proverbs 1029', JBL 107 (1988): 207-24.

30 Hildebrandt, 'Proverbial Pairs', 210.

31 Hildebrandt, 'Proverbial Pairs', 212.

32 Hildebrandt, 'Proverbial Pairs', 219. 
Ruth Scoralick also demonstrates catchword connections in Proverbs. She counts 63 proverb-couplets connected by catchwords in Proverbs 10-15 alone, demonstrating how the sayings in these chapters are compiled as a collection. She supports her conclusion by pointing out that catchword association occurs much more rarely in Proverbs 16-22. For example, Scoralick connects Proverbs 10:2 and 10:3 through the roots רשע (wicked) and (righteous). The same two roots connect Proverbs 10:6 and 10:7, of which the LXX also contains

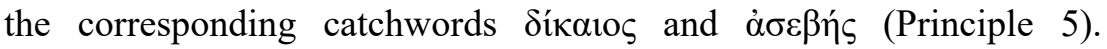
Scoralick finds twenty cases in Proverbs 10-15 with more than one catchword (Principle 3) connecting sayings, and even points out that the four verses of this collection (15:29-32) are linked by the root שמע (hear). ${ }^{33}$ She demonstrates the double-connections between LXX Proverbs 15:27a (which is not in the MT) and 15:28 by the

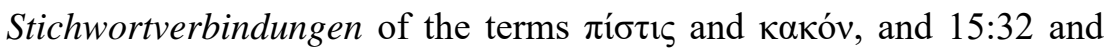

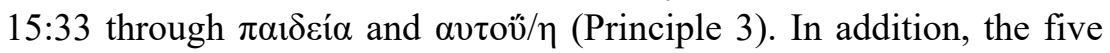
consecutive sayings of LXX Proverbs 15:28-29b all contain words with

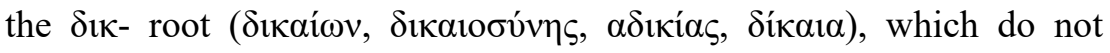
occur in the differently ordered MT. ${ }^{34}$

\subsection{Sirach}

Like Proverbs, the Greek text of Sirach displays catchwords, linking individual proverbs based on association of words. For example, Sirach 3:1-16 contains a list of sayings concerned with duties towards one's parents. George Nickelsburg points out that four consecutive proverbs in Sirach 3 address honouring one's father connected by catchword association (Principle 3): ${ }^{35}$

Sirach 3:3 He who honours a father will atone for sins

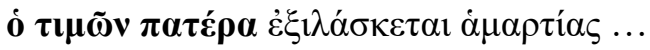

Sirach 3:5a He who honours a father will be gladdened by children ...

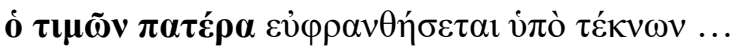

33 Ruth Scoralick, Einzelspruch und Sammlung: Komposition im Buch der Sprichwörter Kapitel 10-15 (BZAW, 232; Berlin: de Gruyter, 1995): 127-29.

34 Scoralick, Einzelspruch und Sammlung, 60.

35 George W. E. Nickelsburg, Jewish Literature Between the Bible and the Misnah: A Historical and Literary Introduction (2nd edn; Minneapolis: Fortress, 2005): 55. 
Sirach 3:6a He who glorifies a father will prolong his days ...

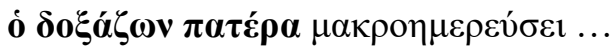

Sirach 3:8 By deed and word honour your father so that a blessing from him might come upon you.

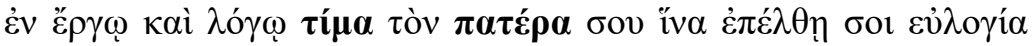

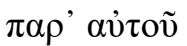

After that, according to Nickelsburg, the saying in 3:8 is then associated with 3:9 with the catchwords 'father' and 'blessing':36

Sirach 3:9a For a father's blessing supports children's houses ...

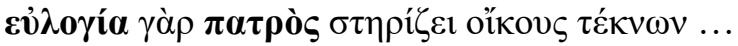

Notably, Luke Cheung points out that the theme of honouring one's father occurs in Sirach 3:1-16 and rarely again (Principle 2), while in Proverbs there are over twenty such sayings, but they are scattered. ${ }^{37}$ This observation supports the notion that these sayings in Sirach are indeed connected by catchword association.

\subsection{Ezekiel}

In an essay entitled 'The Arrangement of the Book of Ezekiel', Cassuto demonstrates how the order of sections of Ezekiel is determined based on association of words. ${ }^{38}$ For example, he demonstrates that 3:22-27 is connected to the next section based on the cords being placed on the prophet in 3:25 and 4:8. Notably, the Old Greek contains the same catch phrase as well (Principle 5). Ezekiel 5, addressed to Jerusalem, and Ezekiel 6, addressed to the mountains of Israel, are connected based on the same phrase, I will bring the sword upon you, occurring in 5:17 and 6:3 (Principle 3). ${ }^{39}$

Cassuto proceeds to demonstrate more catchword association throughout Ezekiel. Another notable example occurs towards the end of Ezekiel. Ezekiel 36:16-38, which describes the Lord cleansing his people and restoring the land, is connected to the seemingly disparate

\footnotetext{
36 Nickelsburg, Jewish Literature, 55.

37 Luke L. Cheung, The Genre, Composition and Hermeneutics of James (Carlisle: Paternoster, 2003): 25.

38 I have edited some instances for better presentation here. See Umberto Cassuto, 'The Arrangement of the Book of Ezekiel' in Biblical and Oriental Studies, Volume 1: Bible (Jerusalem: Magnes; tr. from Hebrew and Italian, 1973): 227-40.

39 Cassuto, 'The Arrangement of the Book of Ezekiel', 230.
} 
vision of the field of dry bones in Ezekiel 17 through the combination of the verb נתוּ (give) and the noun (spirit) in 36:27a, 37:6b, and 37:14a (Principles 1,3). Note that the LXX shows this catchphrase as

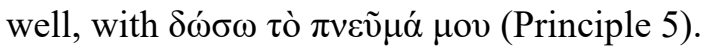

\subsection{Ruth}

The placement of Ruth in the canon shows evidence of catchword association. Several studies have shown that Ruth, which was originally grouped with the Writings and not the Former Prophets in the MT, has Hebrew lexemic connections with the end of Judges and the beginning of 1 Samuel. These observations have led to scholars maintaining that Ruth is meant to be read in connection with Judges and 1 Samuel, which is reflected in the ordering of Ruth between the two documents in the Greek tradition.

Ruth has considerable lexemic connections with the final section of Judges (19-21). R. G. Boling proposes that Ruth was appended to the final episode in Judges, with 'many points of relationship' between the two documents. ${ }^{40}$ Edward F. Campbell points out that both Judges

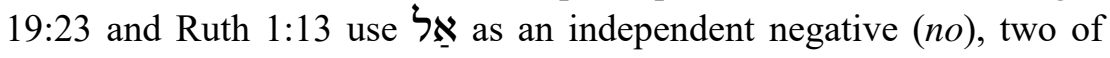
only six OT occurrences (Principles 2, 4). He also points out that the distinct 'idiom' of eating and drinking so that one's heart (ליב) would 'be good' (the root יטב) occurs in the account of the Levite in Judges 19 and also in Ruth 3:7 (Principle 3). ${ }^{41}$ Timothy J. Stone also argues that Ruth should be read in connection with Judges, demonstrating a number of lexemic connections between Ruth 1 and Judges 17-21. The most obvious connection is the phrase indicating the setting of Ruth: (in the days when the judges were judging, Ruth

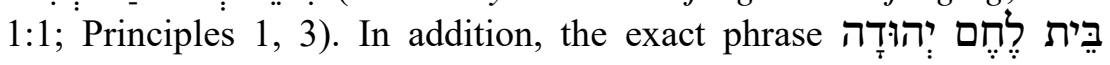
(Bethlehem of Judah), a geographical locator that occurs twice in Ruth $1-2$, occurs repeatedly in the final section of Judges (17:8,9; 19:1,2,8; Principles 3, 4). Finally, Stone highlights a number of scholars who note that both Judges 21:23 and Ruth 1:4 use the root נשא ל לשר to express taking up a wife rather than the much more common לקח (Principles 2,

40 Robert G. Boling, Judges: A New Translation with Introduction, Notes, and Commentary (AB, 6A; Garden City, New York: Doubleday, 1975): 276.

41 Edward F. Campbell, ed., Ruth: A New Translation with Introduction, Notes, and Commentary (AB, 7; Garden City, New York: Doubleday, 1975): 35. Campbell cites Judg. 19:6 and 22 for one's heart being good, but it also occurs in 19:9. Stone points out that the cluster of eat (אכל), drink (שתה), heart (לב), and merry (יטבב) only occurs in Judg. 19:6,21-22, and Ruth 3:7. 
4). He notes that לקח is used commonly for this idiom in Judges (14:3;

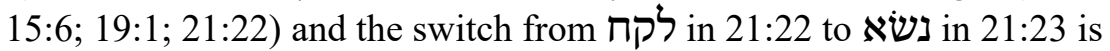
'odd', along with the switch back from נשא in Ruth 1:4 לקח in to לקח in 4:13. He deems the function of נשא in Judges 21:23 and Ruth 1:4 as 'connective' as 'catchwords'. ${ }^{42}$

There are also lexemic links between Ruth and Samuel that suggest that Ruth is meant to be a bridge between Judges and Samuel. The genealogy at the conclusion of Ruth ends with David, whose succession to the throne is chronicled in the books of Samuel (Principle 4), ${ }^{43}$ and the term Ephrathite and Bethlehem of Judah feature at Ruth 1:2 and 1 Samuel 17:12 (Principles 2, 4). But the 'decisive' catchphrase, according to Stone, ${ }^{44}$ is the 'identical' grammatical form of the phrases in Ruth 4:15 and 1 Samuel 1:18 (Principles 2, 4):45

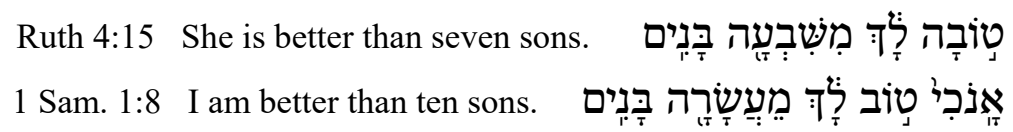

Stone considers this pairing to be a catchphrase connecting Ruth and Samuel at the seams. ${ }^{46}$

If the composition of Ruth is indeed dated after Judges and 1 Samuel, its catchword and catchphrase connections with the two documents suggest that Ruth is meant to be read between them, an ordering that is reflected in the Greek tradition. It follows that Ruth was either originally composed or edited to have these rarely occurring terms and phrases in order to be read in the context of Judges and Samuel.

\subsection{The Book of the Twelve}

It has been observed that the Book of the Twelve holds a specific order using different literary devices, including catchwords. For example, the

\footnotetext{
42 Timothy J. Stone, The Compilational History of the Megilloth: Canon, Contoured Intertextuality and Meaning in the Writings (FAT, 59; Tübingen: Mohr Siebeck, 2013): $120-22$. Stone points out that the Old Greek 'flattens the Hebrew', using $\lambda \alpha \mu \beta \alpha ́ v \omega$ in Judges and Ruth for taking wives.

43 So Tod Linafelt, 'Ruth' in Berit Olam: Studies in Hebrew Narrative \& Poetry, ed. David W. Cotter (Collegeville, Minnesota: Liturgical Press, 1999): xx-xxi.

44 Stone, Compilational History, 125.

45 Daniel I. Block, Judges, Ruth: An Exegetical and Theological Exposition of Holy Scripture (NAC, 6; Nashville: Broadman \& Holman, 1999): 729 n82.

46 Stone, Compilational History, 125.
} 
ending of Hosea and the beginning of Joel share a number of catchwords (Principle 4), suggesting a deliberate attempt to 'strengthen the tie' between them. ${ }^{47}$ Hosea 14:8 contains the roots ישב (live), (wine), דגן (vine), and (grain), which occur in Joel 1:2, 1:5, 1:7, and $1: 10$, respectively. ${ }^{48}$

James Nogalski demonstrates, with his own wooden translations, the occurrence of catchwords linking the writings of the Book of the Twelve together. ${ }^{49}$ In addition to the connections between Hosea and Joel above, Nogalski displays the connections between each writing. Nogalski points to these catchwords connecting each writing to the next as a reading 'logic' for the Book of the Twelve. ${ }^{50}$ He ultimately argues from the evidence of the catchwords that the final form of the Book of the Twelve is a connected whole stitched together through slight alterations in a redaction process. For example, he concludes that Joel and Obadiah were both formed from existing material to fit in between Hosea and Amos, and after Amos, respectively. ${ }^{51}$

$\begin{array}{ll}\text { MT } & \text { LXX } \\ \text { Hosea } & \text { Hosea } \\ \text { Joel } & \text { Amos } \\ \text { Amos } & \text { Micah } \\ \text { Obadiah } & \text { Joel } \\ \text { Jonah } & \text { Obadiah } \\ \text { Micah } & \text { Jonah } \\ \text { Nahum } & \text { Nahum } \\ \text { Habakkuk } & \text { Habakkuk } \\ \text { Zephaniah } & \text { Zephaniah } \\ \text { Haggai } & \text { Haggai } \\ \text { Zechariah } & \text { Zechariah } \\ \text { Malachi } & \text { Malachi }\end{array}$

47 Bo H. Lim, 'Which Version of the Twelve Prophets Should Christians Read? A Case for Reading the LXX Twelve Prophets', Journal of Theological Interpretation 7 (2013): 23.

גפן (vine) occurs again in Joel 1:12.

49 James Nogalski, Literary Precursors to the Book of the Twelve (BZAW, 217; Berlin: de Gruyter, 1993): 20-57. Nogalski demonstrates catchwords linking the writings with the exception of the endings of Jonah and Zechariah. He attributes the omission of catchwords in these two documents to the growth of the Book of the Twelve. Nogalski does, however, demonstrate catchwords in the hymn of Jon. 2:3ff with Mic. 1:1ff, and the conclusion of Proto-Zechariah (8:9ff) with Mal. 1:1ff.

50 Nogalski, Literary Precursors to the Book of the Twelve, 57.

51 James Nogalski, Redactional Processes in the Book of the Twelve (BZAW, 218; Berlin: de Gruyter, 1993): 276-77. 
The LXX, which displays a different order of the twelve prophets, as shown in the table above, also appears to have catchwords connecting them. For example, Hosea and Amos are the only two writings that

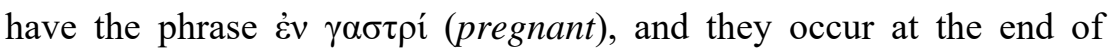
Hosea (14:1) and the beginning of Amos (1:3,13; Principles 2, 4). Micah ends (7:20) with an appeal to God who spoke to the fathers in the former days ( $\pi \alpha \tau \dot{\eta} \rho, \dot{\eta} \mu \varepsilon \rho \alpha)$ and Joel begins with a call to remember the days of their fathers (Joel 1:2; Principles 2, 4).

The phenomenon of catchword association occurring in the Book of the Twelve supports the notion that these pre-existing documents are being stitched together. While it is beyond the scope of this article to speculate on whether the documents were altered to create the links, the fact that catchwords can be detected in the different sequences of the Hebrew and Greek demonstrates intentionality.

\subsection{Qumran}

The practice of gezerah shawah is one possible purpose of juxtaposing disparate texts using common lexemes. This midrashic method, which continued to be used after the writing of James, associates two verses from the Hebrew Bible by comparing similar words that occur in each. With this association, one verse is used to interpret or clarify the other. ${ }^{52}$ Documents uncovered at Qumran have been identified as using this method, as they offer expositions of existing Old Testament passages.

4Q174, or Florilegium, is a midrash on 2 Samuel and Psalms 1-2. In fragment 1,1:10-12, the document quotes 2 Samuel 7:11-14, followed by Amos 9:11. The two sayings are connected by the phrase and I will raise (והקימותי, Principle 3). Notably, the quotation of Amos 9:11 here diverges from the MT, which uses the imperfect אָקִ. This difference, according to Friedrich Avemarie, provides the 'strongest clue for a conscious lexemic association behind the two quotations'. It is unclear whether the variant originated with the author of Florilegium, but it is evident that these disparate sayings are intentionally placed together as the document draws this concept of

52 Michael Chernick, 'Internal Restraints on Gezerah Shawah's Application', JQR 80 (1990): 253. 
'raising up' from these texts. ${ }^{53}$ Notably, the two quoted verses use the same Greek term in the LXX: $\alpha v \alpha \sigma \tau \eta \dot{\sigma \omega}$ (Principle 5).

Manuscript A of the Damascus Document, or CD, offers a midrash on two separate passages in Amos in column 7, Amos 5:26-27, and Amos 9:11, with a clarifying statement in between. All three sentences are connected through the term for booths (סוכת), the construct form of (סטכ):

'And I will expel your king's booth ...'

והגליתי את סכות מלככם (line 14b, quotation of Amos 5:26f) The books of the Torah are the 'booth of the king,'

ספרי התורה הם סוכת המלך

as he said, 'I will raise up the fallen booth of David.'

(line 16a, quotation of Amos 9:11). ${ }^{54}$

\section{כאשר אמר והקימותי את סוכת דוד הנופלת}

George Brooke points out that סכות in line 14b, which is the name of the king Sakkuth in Amos 5:26, is taken as סוכת or booth (construct) in the Damascus Document (Principle 7). ${ }^{55}$ Again, the quotation of Amos 5:26-27 differs from the MT. It contains elements from both

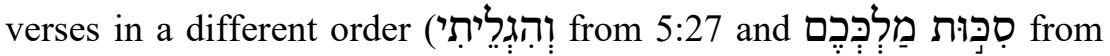
5:26). In addition, the MT describes an exile further beyond Damascus, while the Damascus Document describes an exile to Damascus (Principle 6).

In the War Scroll (1QM), the author places citations of Deuteronomy 7:21 and 20:2-5 together. They are linked by the root קרב (Principle 7):56

... you (are) in our midst, $O$ great and terrifying God (Deut. 7:21)

1QM 10:1b אתה בקרבנו אל גדול ונורא

53 Friedrich Avemarie, 'Interpreting Scripture Through Scripture: Exegesis Based on Lexematic Association in the Dead Sea Scrolls and the Pauline Epistles' in Echoes from the Caves: Qumran and the New Testament, ed. Florentino García Martínez (Leiden: Brill, 2009): 88-89.

54 Translations by Joseph M. Baumgarten and Daniel R. Schwartz, 'Damascus Document (CD)' in Damascus Document, War Scroll, and Related Documents, ed. James H. Charlesworth (The Dead Sea Scrolls: Hebrew, Aramaic, and Greek Texts with English Translations, 2; Tübingen: Mohr Siebeck, 1995): 26-27.

55 George J. Brooke, Exegesis at Qumran: 4QFlorilegium in Its Jewish Context (JSOTSup, 29; Sheffield: JSOT Press, 1985): 307.

56 Brooke, Exegesis at Qumran, 293. 
... saying, 'When you draw near for battle, the priest shall take position and address the people' (Deut. 20:2-3)

1QM 10:2b לאמור בקרבכם למלחמה ועמד הכוהן ודבר אל העם

saying, 'Hear, Israel, you are drawing near today for a battle against your enemies. (Deut. 20:3)

1QM 10:3a: לאמור שמעה ישראל אתמה קרבים היום למלחמה 57 על אויביכמה

The practice of gezerah shawah demonstrates that association of texts using common lexemes was a common Semitic method of interpretation. In each of these instances from Qumran, quotations from different places are placed together, linked by common catchword or catchphrase. While explanations of the deviations from the MT are beyond the scope of this article, these instances show that pre-existing material is placed together according to common lexemes. They also suggest one purpose of associating texts using this method: using one text to interpret another.

\section{Catchwords in James}

Now that we have examined how catchwords are used in Semitic documents, we turn our attention to the Epistle of James, where catchwords often appear to link adjacent units together. Assisting our examination is the fact that James is easily divided into sections, as demonstrated by consensus regarding their delineation. For example, scholars largely designate 1:2-4, 1:5-8, and 1:9-11 as detectible sections. ${ }^{58}$

The document starts with an epistolary greeting (1:1) that ends with

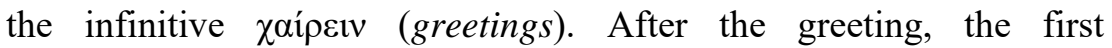

57 Translations by Jean Duhaime, 'War Scroll (1QM; 1Q33; 4Q491-496 = 4QM1-6; 4Q497)' in Damascus Document, War Scroll, and Related Documents, ed. James H. Charlesworth (The Dead Sea Scrolls: Hebrew, Aramaic, and Greek Texts with English Translations, 2; Tübingen: Mohr Siebeck, 1995): 116-17.

58 See, for example, Dale C. Allison Jr, James: A Critical and Exegetical Commentary (ICC; New York: Bloomsbury T\&T Clark, 2013): 79; Scot McKnight, The Letter of James (NICNT; Grand Rapids: Eerdmans, 2011): viii; Robert W. Wall, Community of the Wise: The Letter of James (Valley Forge, Pennsylvania: Trinity, 1997): 47-57; Franz Mußner, Der Jakobusbrief (HThKNT; Freiburg im Breisgau: Herder, 1987): vii; Patrick J. Hartin, James (SP, 14; Collegeville, Minnesota: Liturgical Press, 2003): 64. 
exhortation (1:2) features the noun $\chi \alpha \rho \alpha$ ó (joy, Principle 7). The exhortation concludes in 1:4 with a catchword $\lambda$ eí $\pi \omega$ that links to the next section (Principle 4): 59

James $1: 4 \mathrm{~b}$ so that you may be mature and complete, lacking in nothing. (NRSV)

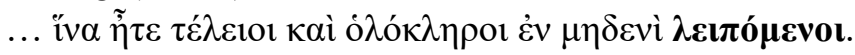

James 1:5a If any of you is lacking in wisdom ... (NRSV)

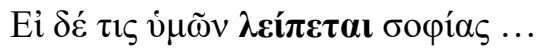

Probably the starkest instance of catchword association in James is between $1: 12$ and 1:13, connected by the cognates $\pi \varepsilon 1 \rho \alpha \sigma \mu o ́ \varsigma$ (trial, 1:12) and $\pi \varepsilon \imath \rho \alpha ́ \zeta \omega$ (tempt, 1:13). Scholars are not at a consensus regarding how 1:12 fits with the rest of the material in James $1 .^{60}$ However, the catchword connects 1:12 and 1:13:

James 1:12a Blessed is anyone who endures temptation ... (NRSV)

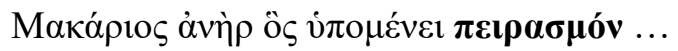

James 1:13 No one, when tempted, should say, 'I am being tempted by God'; for God cannot be tempted by evil and he himself tempts no one.

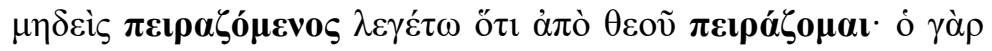

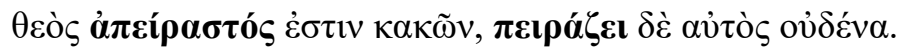

Two factors make the placement of 1:12 particularly complex. First, there is an unmistakable connection of 1:12 with the opening

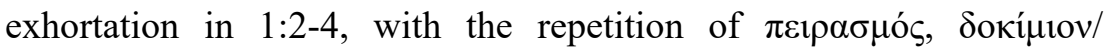

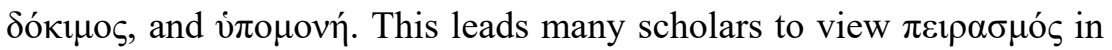

59 Notably, the chain-saying of 1:2-4 links one clause to the next using catchwords,

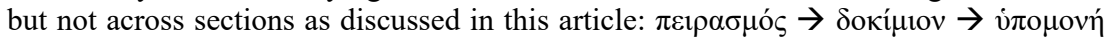
$\rightarrow \tau \varepsilon \dot{\lambda} \lambda \varepsilon \iota_{0}$.

60 Some see Jas 1:12 as connected to the content preceding it. See Dan G. McCartney, James (BECNT Grand Rapids: Baker Academic, 2009): 100; McKnight, Letter of James, 106. Others view Jas 1:12 as connected with the material that follows, with the term $\pi \varepsilon i \rho \alpha \sigma \mu$ ó $\varsigma$ linked with its cognate $\pi \varepsilon 1 \rho \alpha ́ \zeta \omega$ in 1:13-14. See Mußner, Jakobusbrief, 84-86; Allison, James, 225. Still others consider 1:12 to be an isolated statement with no connection to the content that precedes or follows. See Martin Dibelius, James, ed. Helmut Koester (11th ed.; Hermeneia; Philadelphia: Fortress; tr. from German, 1976): 88; Douglas J. Moo, The Letter of James (PilNTC; Grand Rapids: Eerdmans, 2000): 69; Matthias Konradt, Christliche Existenz nach dem Jakobusbrief: eine Studie zu seiner soteriologischen und ethischen Konzeption (SUNT, 22; Göttingen: Vandenhoeck \& Ruprecht, 1998): 21. 
1:12 functioning the same way as it does in $1: 2$, with the traditional rendering of trial, ${ }^{61}$ or difficulty from an external source. Second, the usage of $\pi \varepsilon i \rho \alpha ́ \zeta \omega$ in 1:13-14a connotes a temptation from within, as 1:14b-15 confirm. Thus, this situation begs the question, is there a semantic shift occurring between 1:12 and 1:13 (Principle 7)? ${ }^{62} \mathrm{We}$ will return to this question below.

Another instance of catchword association occurs between 1:21 and 1:22, with the term $\lambda$ ó ${ }^{\circ} \varsigma$ (word). James 1:21 completes a thought begun by 1:19-20, evidenced by the conjunction $\delta$ ió. The next verse appears to begin a new section about being a doer of the word, with $\lambda$ ó $\gamma$ os connecting the two sections.

Chapter 1 of James concludes with two aphorisms that many view as a bridge to chapter 2 . These two sapiential sayings are linked by the only two instances term $\theta \rho \eta \sigma \kappa \varepsilon i ́ \alpha$ (religion, Principle 2), which occur at the adjoining ends (Principle 4):

James 1:26 If any think they are religious, and do not bridle their tongues but deceive their hearts, their religion is worthless. (NRSV)

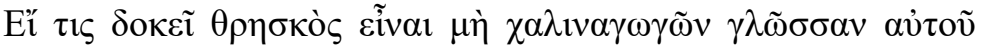

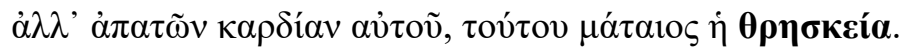

James 1:27 Religion that is pure and undefiled before God, the Father, is this: to care for orphans and widows in their distress, and to keep oneself unstained by the world. (NRSV)

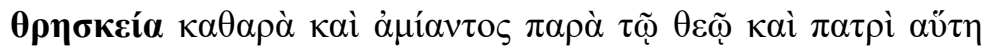

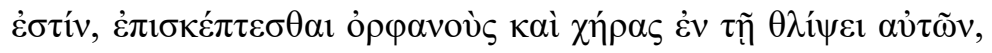

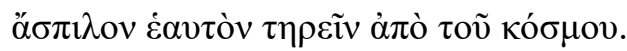

After James 1, catchword association appears in other places in the document. The author of James follows a treatise prohibiting partiality (2:1-12) with two sayings that appear to only have a loose connection.

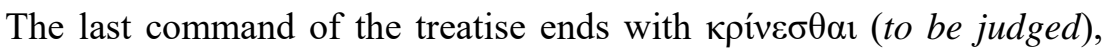
while both sayings in Jas 2:13 feature forms of кpírıs (judgement, Principle 3). They are also connected to each other by the term $\varepsilon \bar{\lambda} \varepsilon \mathrm{s}$ (mercy). The connection between $2: 13 \mathrm{a}$ and $2: 13 \mathrm{~b}$ is particularly

61 NIV, ESV, NASB, CSB, GNB, NRSV, Weymouth.

62 Nicholas Ellis argues that a semantic shift has been perceived because of a desire to clarify roles for God, Satan, and humanity. See Nicholas Ellis, The Hermeneutics of Divine Testing: Cosmic Trials and Biblical Interpretation in the Epistle of James and Other Jewish Literature (WUNT 2, 396; Tübingen: Mohr Siebeck, 2015): 13-14. 
remarkable, as $2: 13 \mathrm{~b}$ appears to be a standalone saying without any logical connection to the content preceding it (Principle 1).

In James 3, the author again follows up the last part of a treatise (3:13-17) with an aphorism that may only be loosely connected $(3: 18)$ via the Greek root for peace (Principle 1):

James 3:17 But the wisdom from above is first pure, then peaceable, gentle, willing to yield, full of mercy and good fruits, without a trace of partiality or hypocrisy.

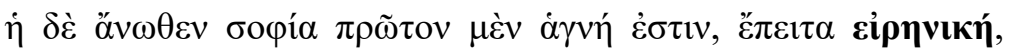

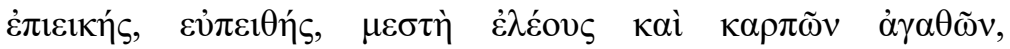

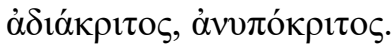

James 3:18 And a harvest of righteousness is sown in peace for those who make peace (NRSV).

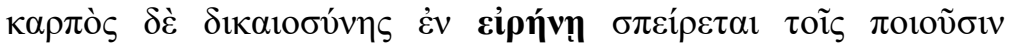

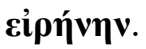

There is a possible usage of catchword association at James 5:12,

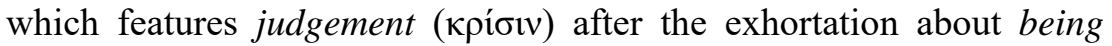

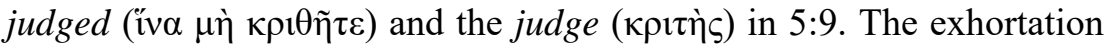
in 5:12 appears disparate from 5:9-11, especially as one considers that 5:11 echoes the blessedness of one who perseveres introduced in the opening portion of the epistle (1:12). This would make 5:11 to be a fitting conclusion to the body of James. Furthermore, the disparity of 5:9-11 and 5:12 is bolstered by the fact that the command in 5:12 begins with $\pi \rho$ ò $\pi \alpha ́ v \tau \omega v$, a common element in Greek letter endings. ${ }^{63}$ The injunction to let your 'yes' be yes and your 'no' be no in the latter half of 5:12 is in the Jesus tradition, as it occurs in the sayings of Jesus at the Sermon on the Mount (Matt. 5:37). The use of the Jesus tradition bolsters the case that at least this part of this command is pre-existing (Principle 1). While Jesus' command continues with a clause which warns that disobedience will result in association with the evil one (Matt. 5:37b), the command in James contains a different clause, one that appeals to judgement (Jas 5:12b). This difference highlights the possibility that the author or compiler of James has amended the saying

63 See Francis Xavier J. Exler, 'The Form of the Ancient Greek Letter: A Study in Greek Epistolography' (Ph.D. dissertation, Catholic University of America, 1923): $113-14$. 


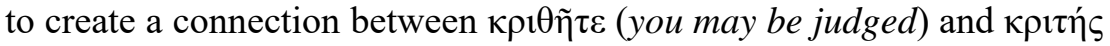
(judge) in 5:9 and кpíoı (judgement) in 5:12.

The final sayings of James (5:13-20) contains a series of exhortations that seem difficult to group together. Scholars are split on whether the healing conveyed in James 5:16 is connected to the sick person in $5: 14-15,{ }^{64}$ thus pointing to the possibility that $i \alpha \theta \tilde{\eta} \tau \varepsilon$ refers to physical healing as well as the spiritual connection with sins in 5:16. However, given the author's penchant for catchwords in the rest of the document, one can view 5:14-15 and 5:16 as disparate, connected only

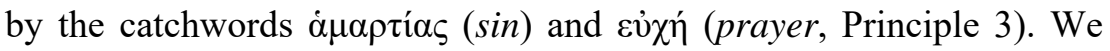
will explore the implications of this designation below.

\section{Implications for the Study of James}

What implications can we draw for James as we identify catchword associations in light of similar constructions Semitic documents? Here are four proposals.

First, the identification of catchwords alone cannot categorise James into one genre of literature. This conclusion stands against the contention of Dibelius that James falls into the genre of paraenesis. The only identifiable characteristic of paraenesis identified by Dibelius in the categorisation of James is the usage of catchwords. ${ }^{65}$ The survey above demonstrates that literature from other genres shows catchwords as well. Thus, one needs more support than catchwords alone to place James into the genre of paraenesis. ${ }^{66}$

Second, catchword association in James may be an indication of its provenance. The usage of catchwords may point to some of the content of James being pre-existing material. Documents surveyed that contain pre-existing material above include Leviticus, Sirach, Judges, Samuel, and the Dead Sea Scrolls. The notion that James is made up of preexisting material is not new ground, as scholars have already suggested that at least some of James is traditional material, without using Semitic

64 For a clear delineation of the different views on these verses, see Chris A. Vlachos, James (Exegetical Guide to the Greek New Testament; Nashville: B\&H Academic, 2013): 186-89.

65 See Dibelius, James, 5-6.

66 McCartney questions Dibelius' conclusion, pointing to 'the paucity of evidence for paraenesis as a generic form as opposed to a rhetorical device'. See McCartney, James, $284 \mathrm{n} 8$. 
catchwords to support it. ${ }^{67}$ However, the Semitic documents that display catchword association offer further support to this conclusion, as they highlight the possibility that the author could have stitched together pre-existing material, sometimes by catchword.

Third, the association by catchwords in James shows that the epistle can be purposefully assembled even if the individual sections do not show a logical progression. Even with its clearly delineated sections, James has proven difficult to outline into larger sections and subsections. Martin Luther lamented that the author of James 'throws things together so chaotically ... and tossed them off on paper' ${ }^{68}$ Martin Dibelius likewise asserts that James is atomistic and largely has 'no continuity of thought whatsoever' ${ }^{69}$ However, James displays similar elements with Semitic documents such as Proverbs, Sirach, and Ezekiel, each of which show intentionality without a having logical progression. The fact that many of these documents surveyed above predate Hellenization highlights the possibility that James can be intentionally arranged without necessarily reflecting logical progression. Thus, attempts to decipher an outline of progressive logic for all of James, especially ones that follow Graeco-Roman patterns of rhetoric, ${ }^{70}$ may be misguided.

Indeed, those who have attempted to demonstrate a logical structure in James have come up with many different outlines, which suggests the futility of the task itself. Proposals have been made from scholars using different methods of determining structure in James, including a

67 Davids, for example, proposes a two-stage hypothesis for James, the first being a series of homilies and the second a compilation into an epistle by a later redactor. See Peter H. Davids, The Epistle of James (NIGTC; Exeter: Paternoster, 1982): 12-13. For a similar view, see Ralph P. Martin, James (WBC; Waco, Texas: Word, 1988): lxxvii. Also, see Richard Bauckham, James: Wisdom of James, Disciple of Jesus the Sage (London: Routledge, 1999): 108-11; Mark E. Taylor, 'Recent Scholarship on the Structure of James', CurBR 3 (2004): 89.

68 Martin Luther, 'Prefaces to the New Testament' in Word and Sacrament I, ed. E. Theodore Bachman, vol. 35 of Luther's Works, ed. Helmut T. Lehmann (Philadelphia: Muhlenberg, tr. from German, 1960): 397.

69 Dibelius' evaluation of the structure of James is based on his perception that paraenesis lacks continuity. Dibelius, James, 5-6.

70 For example, see Wilhelm H. Wuellner, 'Der Jakobusbrief im Licht der Rhetorik und Textpragmatik', LB 43 (1978): 5-66; Duane F. Watson, 'James 2 in Light of Greco-Roman Schemes of Argumentation', NTS 39.01 (1993): 94; Hubert Frankemölle, 'Das semantische Netz des Jakobusbriefes: Zur Einheit eines umstrittenen Briefes', BZ 34 (1990): 161-97. 
chiastic arrangement, ${ }^{71}$ a grand inclusio, ${ }^{72}$ or a repeated pattern. ${ }^{73}$ These and other approaches have produced vastly differing results without a consensus. Regarding this lack of consensus, Richard Bauckham quips, 'one suspects that something must be wrong with the goal that is being attempted' ${ }^{74}$

Fourth, the prominence of catchword association in James 1 relieves the exegete from the task of harmonising adjacent sections of text. The most palpable example of this principle is the disparate usage of the noun $\pi \varepsilon \iota \rho \alpha \sigma \mu$ ó (trial) in James 1:12 and the verb $\pi \varepsilon \iota \rho \alpha ́ \zeta \omega ~(t e m p t)$ in 1:13-14. While the NRSV renders them respectively as temptation and tempt, the verb in 1:12 appears to refer to a trial or external difficulty, especially in light of the other repeated words between 1:2-3 and 1:12. With the Semitic instances in view, one can be content with different connotations of the same cognate in adjacent sections of text (Principle 7). Thus, the traditionally disparate renderings of trial and tempted in James 1 can be kept without reservation, as 1:12 and 1:13 do not have to be semantically linked. Notably, Codex Alexandrinus, with its ekthesis paragraph markers, indicates that James 1:12 should stand on its own, as both James 1:12 and 1:13 start with ekthesis markers.

Another example of the relief from the need for harmonisation across passages is the connection between 5:14-15 and 5:16, highlighted above. The examination of catchword association supports the possibility that these passages are connected only by the association of prayer and sins. Upon further examination, there are several other reasons to consider 5:14-15 and 5:16 to be disparate sections (Principle 1). First, $5: 16$ does not reflect the pattern displayed in three scenarios outlined in 5:13-14: a protasis featuring $\tau \ll \varsigma$ and an apodosis which includes a third person imperative. Second, the explicit connection between 5:14-15 and 5:16 is not healing but prayer, with which the example of Elijah is consistent. Third, 5:15 and 5:16 diverge in other

71 H. I. Cladder, 'Die Anlage des Jakobusbriefes', ZKT 28.1 (1904): 37-57; James M. Reese, 'The Exegete as Sage: Hearing the Message of James', BTB 12 (1982): 82-85; Robert B. Crotty, 'The Literary Structure of the Letter of James', ABR 40 (1992): 4557.

72 Timothy B. Cargal, Restoring the Diaspora: Discursive Structure and Purpose in the Epistle of James (Atlanta: Society of Biblical Literature, 1993); Todd C. Penner, The Epistle of James and Eschatology: Re-Reading an Ancient Christian Letter (JSNTSup, 121; Sheffield: Sheffield Academic Press, 1996).

73 Fred O. Francis, 'The Form and Function of the Opening and Closing Paragraphs of James and I John', ZNW 61 (1970): 118.

74 Bauckham, Wisdom of James, 61. 
ways: the former has a specific command with aorist imperatives for a single person, while the latter has a general command with present imperatives for a group. Fourth, the term $i \alpha \theta \tilde{\eta} \tau \varepsilon$ in 5:16 most likely refers to spiritual healing from sin rather than physical healing. There is no indication that the parties in 5:16 need physical healing, and every instance of ióo $\mu \alpha 1$ associated with sins and lawlessness in the LXX and intertestamental literature refers to spiritual healing, namely God's mercy and forgiveness on the people (Deut. 30:3; 2 Chr. 7:14; 30:20; Ps. 40:5; 106:20; Isa. 6:10; 53:5; 57:17; Jer. 3:22; Odes 14:41; cf. 1 Pet. 2:24). Thus, the existence of catchwords in James can make the exegete content determining the healing in 5:16 to be referring only to spiritual healing of the sins being confessed; it is not connected to the physical ailments of 5:14-15. Again, Codex Alexandrinus notably begins a new paragraph with an ekthesis marker and a large space between 5:15 and 5:16, indicating the scribe's view that this verse is a disparate thought.

The comparison of James with Semitic documents that display catchword association opens up new avenues of enquiry regarding the structure, provenance, and interpretation of this epistle. In addition, it calls into question other avenues of enquiry, particularly those which attempt to find progressive logic in the entirety of James. 